\title{
ĐÁNH GIÁ KẾT QUẢ PHẪU THUẬT CÁT THÙY PHỔI NỘI SOI ĐIỀU TR! UNG THƯ PHỔI KHÔNG PHẢI TỂ BÀO NHỎ TẠI BỆNH VIỆN ĐÀ NÃNG
}

Thân Trọng Vü*

\section{TÓM TẮT}

50 bệnh nhân được phẫu thuật cắt thùy phổi nội soi điều trị ung thư phổi không phải tế bào nhỏ từ $9 / 2011$ đến $3 / 2018.50$ bệnh nhân tuổi từ 17 tháng đến 73tuổi, nam ( 36 bn, 72\%), nữ (14 bn, 28\%). $98 \%$ bệnh nhân được thực hiện phẫu thuật thành công, $2 \%$ bệnh nhân chuyển sang mở ngực,biến chứng nhẹ với tỷ lệ cho phép, không có tai biến trong mổ, không có tử vong.

Từ khóa: Phẫu thuật cắt thùy phổi nội soi, Bệnh Viện Đà Nẵng

\section{SUMMARY}

EVALUATE THE RESULTS OF VIDEO THORACOSCOPIC SURGERY LOBECTOMY FOR NON SMALL LUNG CANCER AT THE DANANG HOSPITAL

All patients of non small cell lung cancer had been operated by video thoracoscopic surgery lobectomy at the Da Nang hospital from 09/2011 to $3 / 2018$. There were 50 patients of non small lung cancer to be operated by VTS lobectomy at the Da Nang hospital. Overall, thoracoscopy was successful in 49 cases $(98 \%)$. Conversion to formal thoracotomy was required in 1 case $(2 \%)$ secondary to bleeding. No mortality, no morbidity, acceptable complication rate.

Keywords: Video Thoracoscopic surgery lobectomy, the Da Nang hospital

\section{I. ĐẶT VẤN ĐỀ}

Phẫu thuật lồng ngực đã được biết từ lâu. Đây là một phẫu thuật lớn, gây đau nhiều nhất, thời gian hồi phục kéo dài trước khi bệnh nhân có thể hoạt động bình thường và trở lại làm việc [1],[2].
Khái niệm phẫu thuật nội soi lồng ngực (PTNSLN) được Hans Christian Jacobaeus giới thiệu đầu tiên năm 1910[3]. Năm 1992, Roviaro. G ở Ý mô tả ca cắt thùy dưới phổi phải đầu tiên bằng video assisted thoracic surgery (VATS) ở bệnh nhân nam 71 tuổi bị ung thư tuyến phổi[6]. Hơn hai thập kỉ qua, VATS không ngừng phát triển và dần dần được xem như là phẫu thuật thay thế cho mổ hở trong ung thư phổi không phải tế bào nhỏ giai đoạn sớm.

Tại Việt Nam, Cắt thùy phổi nội soi được thực hiện tại Bệnh Viện Việt Đức, Bệnh Viện Chợ Rẫy và một số Bệnh Viện Lớn Khác. Hiện tại chưa có nhiều nghiên cứu về loại hình phẫu thuật này.

Năm 2011, Bệnh Viện Đà Nẵng triển khai phẫu thuật nội soi lồng ngực để u phổi. Cắt thùy phổi nội soi điều trị ung thư phổi không phải tế bào nhỏ vẫn còn tranh cãi về chỉ định, bệnh viện Đà Nẵng chưa có công trình nghiên cứu về phẫu thuật này. Vì vậy, chúng tôi thực hiện nghiên cứu: "Đánh giá kết quả phẫu thuật cắt thùy phổi nội soi điều trị ung thư phổi không phải tế bào nhỏ tại Bệnh Viện Đà Nẵng" nhằm mục tiêu:

Nhận xét đặc điểm lâm sàng và cận lâm sàng của ung thư phổi không phải tế bào nhỏ

Đánh giá kết quả sớm phẫu thuật cắt thùy phổi nội soi điều trị ung thư phổi không phải tế bào nhỏ tại Bệnh Viện Đà Nẵng

\section{II. ĐỐI TƯợng VÀ PHƯớng PHÁP NGHIÊN CÚU}

2.1 Đối tượng : 50 bệnh nhân được thực

* Bệnh viện Đà Nã̃ng

Nguoòi chịu trách nhiệm khoa học: Ths Bs Thân Trọng Vũ

Ngày nhận bài: 01/05/2018 - Ngày Cho Phép Đăng: 20/05/2018

Phản Biện Khoa học: PGS.TS. Đặng Ngọc Hùng

GS.TS. Lê Ngọc Thành 
hiện kĩ thuật cắt thùy phổi nội soi điều trị ung thư phổi không phải tế bào nhỏ tại Bệnh Viện Đà Nẵng từ $9 / 2011$ đến $3 / 2018$

2.1.1. Tiêu chuẩn chọn bệnh: Tất cả bệnh nhân được mổ nội soi cắt thùy phổi điển hình điều trị u phổi tại khoa ngoại lồng ngực bệnh viện đà nẵng từ $9 / 2011$ đến $3 / 2018$.

\subsubsection{Tiêu chuẩn loại trù̀}

- Bệnh nhân được cắt phổi hình chêm nội soi

- Giải phẫu bệnh lý sau mổ không phải ung thư phổi không phải tế bào nhỏ.

- Hồ sơ bệnh án không đầy đủ ( mất phim CT Scanner...)

\subsection{Phương pháp nghiên cứu}

2.2.1. Thiết kế nghiên cúu: Nghiên cứu hồi cứu, mô tả cắt ngang

\subsubsection{Phuơng pháp thu thập số liệu:}

- Dựa vào hồ sơ bệnh án thu thập dữ liệu về tuổi, giới

- Vị trí khối u trên CT scanner ngực.

- PET-CT: Đo Max Suv, tầm soát di căn

- Chẩn đoán sơ bộ giai đoạn TNM trước mổ (UICC 2002): dựa vào kích thước $\mathrm{u}$, sự liên quan màng phổi tạng và sự hiện diện của hạch trên $\mathrm{CT}$ scanner, tình trạng thông khí của thùy phổi có $u$, nội soi phế quản, IRM sọ não, siêu âm bụng tổng quát, siêu âm vùng cổ và CT bụng.

- Thời gian mổ, lượng máu mất, tai biến trong mổ, biến chứng sau mổ, thất bại chuyển mổ hở, thời gian nằm viện, số ngày thuốc giảm đau dạng tiêm.

- Kết quả giải phẫu bệnh sau mổ, giai đoạn TNM sau mổ (UICC 2002).

\subsection{Phương pháp phẫu thuật}

- Gây mê nội khí quản Carlens, bệnh nhân nằm nghiêng hơi ngữa
- Vị trí phẫu thuật viên: phía lung bệnh nhân đối với u phổi phải và phía bụng bệnh nhân đối u phổi trái.

- Lỗ trocart thứ nhất: $10 \mathrm{~mm}$ dùng cho camera ở liên sườn 7 hoặc 8 trên đường nách giữa.

- Lỗ trocart thứ hai: 10mm ở lien sườn 6 tên đường nách trước.

- Lỗ trocart thứ ba: $5 \mathrm{~mm}$ ở cạnh đỉnh xương bả vai đối với phổi phải và liên sườn 4 nách trước đối với phổi trái

- Thứ tự cắt tĩnh mạch phổi, các nhánh động mạch phổi, phế quản thùy, cắt cầu nhu mô, nạo hạch rốn phổi và trung thất. Tuy nhiên thứ tự này có thể thay đổi tùy vị trí thùy phổi được cắt.

- Thùy phổi sau khi được cắt được cho vào bao nylon và lấy ra ngoài qua lỗ trocart thứ hai.

- Rửa sạch khoang màng phổi, kiểm tra tình trạng dò khí miệng cắt phế quản, diện cắt cầu nhu mô.

- Đặt dẫn lưu qua lỗ trocart thứ nhất

- Đóng các lỗ trocart

- Các bệnh phẩm được làm giải phẫu bệnh: khối u, các nhóm hạch

2.4. Xử lý số liệu: phương pháp thống kê thông thường

\section{KẾT QUẢ NGHIÊN CÚU}

50 trường hợp cắt thùy phổi nội soi điều trị ung thư phổi không phải tế bào nhỏ tại Bệnh Viện Đà Nẵng từ tháng 9/2011 đến 3/2018.

3.1 Đặc điểm chung: Tuổi: nhỏ nhất: 23; lớn nhất: 73 tuổi; trung bình: 46,2; Nam: 36(72\%), nữ: 14 (28\%) .

\section{2. Đặc điểm lâm sàng}


Bảng 3.1. Triệu chứng cơ năng

\begin{tabular}{|l|c|c|}
\hline Triệu chứng lâm sàng & n & \% \\
\hline Đau ngực & 19 & 38 \\
\hline Ho khan & 15 & 30 \\
\hline Ho ra máu & 5 & 10 \\
\hline $\begin{array}{l}\text { Đau ngực, ho khan hoặc ho ra } \\
\text { máu }\end{array}$ & 11 & 22 \\
\hline Tổng & 50 & 100 \\
\hline
\end{tabular}

Đau ngực chiếm tỷ lệ cao nhất: $38 \%$

\subsection{Vị trí thùy phổi được phẫu thuật}

Bảng 3.2. Vị trí thùy phổi được phẫu thuật

\begin{tabular}{|l|c|c|}
\hline Vị trí u phổi & $\mathbf{N}$ & \% \\
\hline Thùy trên phổi phải & 20 & 40 \\
\hline Thùy trên phổi trái & 7 & 14 \\
\hline Thùy giữa phối phải & 3 & 6 \\
\hline Thùy dưới phổi phải & 13 & 26 \\
\hline Thùy dưới phổi trái & 7 & 14 \\
\hline Tổng & 50 & 100 \\
\hline
\end{tabular}

Nhận xét: phẫu thuật nội soi được thực hiện tất cả các vị trí của thùy. Phổi phải chiếm ưu thế $69 \%$

3.3 Đặc điểm PET-CT: 15 bệnh nhân có u phổi được chụp PET-CT trước mổ trong tổng số 50 bệnh nhân u phổi được mổ (30 \%). Giá trị Max SUV nhỏ nhất: 8,97, lớn nhất: 20,27, trung bình:13,44

\section{4. Đặc điểm phẫu thuật}

Thời gian mổ: ngắn nhất: 90 phút, dài nhất: 180 phút, trung bình:162 phút. Lượng máu mất: 10-30 ml. Thất bại chuyển mổ hở: 1 trường hợp $(2 \%)$

\subsection{Kết quả giải phẫu bệnh sau mổ}

Bảng 3.3. Kết quả giải phẫu bệnh sau mổ

\begin{tabular}{|l|c|c|}
\hline Giải phẫu bệnh sau mổ & $\mathrm{n}$ & $\%$ \\
\hline Carcinoma tuyến phổi & 43 & 86 \\
\hline Carcinoma tế bào vảy & 7 & 14 \\
\hline Tổng & 50 & 100 \\
\hline
\end{tabular}

Nhận xét: Ung thư tuyến chiếm ưu thế ( 86\%) 


\subsection{Tai biến, Biến chứng, tử vong, tỷ lệ chuyển mổ hở}

Bảng 3.4. Tai biến, Biến chứng, tử vong, tỷ lệ chuyển mổ hở

\begin{tabular}{|l|c|c|}
\hline Biến chứng và tử vong & $\mathrm{N}$ & $\%$ \\
\hline Chảy máu trong mổ & 1 & 2 \\
\hline Rỉ dịch huyết thanh tại vị trí dẫn lưu sau mổ & 1 & 2 \\
\hline Dò khí kéo dài & 0 & 0 \\
\hline Tử vong trong mổ và 30 ngày sau mổ & 1 & 2 \\
\hline Chuyển mổ hở & 49 & 98 \\
\hline Mổ nội soiThành công & & \\
\hline
\end{tabular}

Nhận xét: Tỷ lệ thành công cao: 98\%

\subsection{Phân loại giai đoạn trước và sau mổ}

Bảng 3.5. Giai đoạn $\mathrm{K}$ phổi trước và sau mổ

\begin{tabular}{|l|c|c|c|c|}
\hline \multirow{2}{*}{ Giai đoạn } & \multicolumn{2}{|c|}{ Trước mổ } & \multicolumn{2}{c|}{ Sau mồ } \\
\cline { 2 - 5 } & $\mathrm{n}$ & $\%$ & $\mathrm{n}$ & 6 \\
\hline IA & 5 & 10 & 1 & 2 \\
\hline IB & 3 & 34 & 13 & 26 \\
\hline IIA & 17 & 50 & 18 & 36 \\
\hline IIB & 25 & 0 & 15 & 100 \\
\hline IIIA & 0 & 100 & 50 & 30 \\
\hline Tổng & 50 & 6 & & \\
\hline
\end{tabular}

Nhận xét: giai đoạn sau mổ có sự thay đổi nặng hơn so với trước mổ

- Thời gian nằm viện: dài nhất: 14 ngày, ngắn nhất :6 ngày và số ngày dùng thuốc giảm đau dạng tiêm: 1-2 ngày.

\section{BÀN LUẬN}

\subsection{Một số đặc điểm chung:}

Phân bố về giới của bệnh nhân trong nhóm nghiên cứu với nam chiếm ưu thế (72\%). Trong 1100 case của Mc Kenna [5] tỷ lệ nam, nữ lần lượt là $45,9 \%, 54,1 \%$. Cắt thùy phổi nội soi có thể thực hiện được ở bệnh nhân lớn tuổi nếu đánh giá chức năng tim, phổi cho phép, chỉ định này phù hợp với quan điểm của các tác giả khác [3],[5],[8].

\subsection{Các đặc điểm của kỹ thuật cắt thùy} phổi nội soi:

Chúng tôi thực hiện cắt thùy cho tất cả các vị trí thùy của phổi trong đó phổi phải chiếm ưu thế $(72 \%)$. Mc Kenna [5] mổ phổi phải (59,4\%).Một trường hợp chảy máu khi nạo hạch chúng tôi chuyển sang mổ hở do an toàn $(2 \%)$, không có trường hợp nào tử vong trong và sau mổ 30 ngày. Hai trường hợp dò dịch màng phổi 
tại vị trí dẫn lưu nhập viện lại điều trị ổn định, một trường hợp $(2 \%)$ dò khí kéo dài theo dõi và ổn định .Sandra. C Tomaszek [7] phẫu thuât 56 bệnh nhân không có trường hợp nào tử vong trong mổ. Yamamoto. K [9] phẫu thuật cho 502 bệnh nhân ghi nhận tử vong sau mổ là $0,3 \%$. Mc Kenna[5] không có tử vong trong mổ, tỷ lệ tràn khí màng phổi là $(5 \%)$. Số lượng phẫu thuật của chúng tôi còn nhỏ nhưng kết quả đáng khích lệ.

Thời gian phẫu thuât trong nhóm nghiên cứu của chúng tôi là 162 phút trong đó cắt thùy trên phổi trái lâu nhất và cắt thùy giữa là ngắn nhất. Sandra. C Tomaszek [7] có thời gian phẫu thuật trung bình là 139 phút. Càng ngày chúng tôi càng giảm bớt thời gian mổ này.

Lượng máu mất trong mổ không đáng kể, chỉ thấm vài gạc con ( $10-30 \mathrm{ml}$ máu). Mc Kenna [5] có $4.1 \%$ cần truyền máu trong mổ. Bệnh nhân sau mổ được dùng thuốc giảm đau dạng tiêm 1-2 ngày. Bệnh nhân nằm viện từ $6-14$ ngày trung bình là 6,5 ngày. Một trường hợp $(2 \%)$ nằm dài ngày ( 14 ngày) vì sau mổ có dò khí màng phổi nên chúng tôi lưu theo dõi. Mc Kenna [5] có thời gian nằm viện trung bình 4,78 ngày trong đó có $20 \%$ xuất viện vào ngày thứ 1 đến ngày thứ 2 sau mổ. Trong tương lai chúng tôi sẽ mạnh dạn cho ra viện sớm.

Chúng tôi thực hiện thành công 49 trong số 50 bệnh nhân (98\%), một bệnh nhân trong khi mổ nạo hạch vỡ chảy máu gây tẩm nhuộm máu phẫu trường cầm máu không được nên chúng tôi chuyển mổ hở để xử lý.

\subsection{Chỉ định cắt thùy phổi nội soi trong k phổi}

Chỉ định cắt thùy phổi của chúng tôi cho bệnh phổi lành tính và ác tính. Việc chẩn đoán khối u phổi là ung thư và giai đoạn bệnh trước mổ là khó khăn. Có bệnh nhân chọc xuyên thành cho kết quả ung thư phổi nhưng có bệnh nhân không thể chọc được do $\mathrm{u}$ nhỏ. Chúng tôi dựa vào đặc điểm $\mathrm{CT}$ scanner ngực và sau này $\mathrm{PET}$ $\mathrm{CT}$ được áp dụng trong thời gian gần đây : 15 bệnh nhân được chụp PET-CT (30\%).Chúng tôi thực hiện cắt thùy phổi nội soi cho 50 bệnh nhân có tổn thương nghi ngờ $\mathrm{k}$ phổi trước mổ và giai đoạn dự đoán là sớm. kết quả sau mổ ). Qua 50 trường hợp, chúng tôi nhận thấy giai đoạn bệnh có sự biến đổi trước và sau mổ. Đối với các bệnh nhân trước mổ, chúng tôi chủ động lựa chọn bệnh từ giai đoạn II trở xuống nhưng kết quả giải phẫu bệnh cuối cùng (hạch trung thất có di căn ) nên giai đoạn III tăng lên $(30 \%)$. Thời gian sống thêm sau mổ ở bệnh nhân $\mathrm{k}$ phổi vẫn chưa có sự đánh giá cụ thể. Vì vậy, chúng tôi sẽ nghiên cứu kết quả trung và dài hạn để đánh giá tốt hơn về phẫu thuật này.

\section{KẾT LUẬN:}

Triệu chứng lâm sàng thường gặp của ung thư phổi không phải tế bào nhỏ là đau ngực $(38 \%)$. Ung thư tuyến gặp nhiều nhất $(86 \%)$. Bệnh Viện Đà Nẵng đã áp dụng cắt thùy phổi nội soi điều trị ung thư phổi không phải tế bào nhỏ hiệu quả, an toàn với tỷ lệ thành công $98 \%$, không có tử vong trong và sau mổ.

\section{TÀI LIỆ THAM KHẢO}

1. Nguyễn Hoài Nam, “ Những cải tiến kỹ thuật trong phẫu thuật nội soi lồng ngực ", Ngoại khoa, 2003,53 (6), 12-23.

2. Nguyễn Hoài Nam, “ Phẫu thuật nội soi lồng ngực ”, Nhà xuất bản y học, 2006, 1 - 271.

3. Darius Dziedzic and Tadeusz Orlowski, “ The role of VAST in lung cancer surgery: Current status and prospects for development", Minim invasive surgery.2015;2015:938430.

4. Jonh D. Mitchell, " Techniques of VAST lobectomy", Journal of Thoracic Disease,2013, 5(3), 177-181. 
5. McKenna RJ Jr , "Video-assisted thoracic surgery lobectomy: experience with 1100 case", Ann Thoracic Surg, 2006,81(2), 421-426.

6. Rovario G, Varoli.F , “ Long term survival after video thoracoscopic lobectomy for stage I lung cancer", Chest, 2004,126(3), 725-732.

7. Sandra C. Tomaszek et al, "Clinical outcomes of Video-Assisted Thoracoscopic Lobectomy", Mayo Clin Proc, 2009,84(6), 509-513.
8. Van Schil Paul E, Bram Balduyck et al , “ Surgical treatement of early - stage nonsmall cell lung cancer", EJC Suppl,2013, 11(2), 110-122.

9. Yamamoto K et al, “ Long-term survival after video-assisted thoracic surgery lobectomy for primary lung cancer", Ann Thorac Surg, 2010,89(2), 353-359 [Abstract]. 